\title{
Specific competences in the Tuning Latin America Project: their degree of importance and achievement among a sample of psychology students
}

\author{
Denise Benatuil and María Juliana Laurito*
}

doi: http://dx.doi.org/10.18543/tjhe-4(2)-2017pp333-351

\begin{abstract}
The implementation of the competence-based education approach at university level is a vehicle for the global transformation of the current Higher Education system. Over the past few decades, psychology has increasingly focused on the identification of core competences in the education of psychologists. The U.S., Canada and Europe have adopted competence-based education approaches. More recently, in 2013 the Tuning Latin America Project introduced the challenge to reach agreement on the education of psychologists in the region. The purpose of this research is to analyse the degree of importance and perceived achievement of the specific competences set out in the Tuning Latin America Project, among a sample of 100 advanced psychology students of a private university in the City of Buenos Aires. For such purpose, the Specific Competences Survey for students of the Tuning Latin America Project was used. All the competences obtained high ratings in terms of importance, in particular those related to professional ethics. In addition, the respondents considered that most of the competences are thoroughly developed during their university training. To conclude, further studies and analyses need to be carried out in order to identify current educational needs for psychologists and thus enhance quality and adjust psychological practice to current social needs.
\end{abstract}

Keywords: competences; training; Tuning; psychology; students.

\section{Introduction}

Over the past two decades, psychology has increasingly focused on the identification of core competences as a basis to define and measure students' learning outcomes. ${ }^{1}$

* Denise Benatuil (dbenatuil@iname.com),PhD in Psychology, is Director of Undergraduate Psychology Studies at Palermo University (Argentina). María Juliana Laurito (mlauri@ palermo. edu), Master's in Higher Education (MEs), Secretary of Psychology Degree Programme at Palermo University (Argentina). More details are available at the end of this article.

${ }^{1}$ Nadya Fouad et al., "Competency benchmarks: A model for understanding and measuring competence in professional psychology across training levels," Training and Education in Professional Psychology 3, no. 4 (2009): 8. 
The final version of the "International Declaration of Core Competences in Professional Psychology" was released this year at the International Congress of Psychology held in Yokohama. The Declaration states that the global professional identity of psychologists can be improved through the identification of a set of core competences that define professional practices. ${ }^{2}$

In addition, the Declaration identifies a set of internationally recognized competences that can serve as a basis for a coherent global professional identity and for equating professional training systems. ${ }^{3}$

In the United States and Canada, the Committees on Accreditation adopted competence-based approaches in the 1990s. ${ }^{4}$ In Europe, in 2003 the Project "EuroPsy: A European Certificate in Psychology" sought to define the generic and specific competences of psychologists, as well as criteria for the creation of a European Certificate in Psychology. ${ }^{5}$ More recently, in 2013 the Tuning Latin America Project included the area of Psychology in its second phase, thus introducing the challenge to reach agreement on the education of psychologists in the region. ${ }^{6}$

In Argentina, the psychology degree course came to be included in Article 43 of the Law on Higher Education $N^{\circ} 24521$ sanctioned in 1995. The course thus gained the status of a public interest degree course, as it was considered that "its exercise may compromise public interest by directly putting at risk the inhabitants' health, security, rights or education". This implies an obligation to evaluate and accredit the career, based on nationally defined quality standards. The respective careers must be accredited periodically by the National Commission of Evaluation and University Accreditation (CONEAU) or by private entities constituted for this purpose duly recognized. ${ }^{7}$

In addition, in 2009 Argentina's Ministry of Education approved the Standards for training in psychology. According to such Standards, training in psychology must include general courses based on a twofold approach -

${ }^{2}$ International Project on Competence in Psychology, "International Declaration on Core Competences in Professional Psychology," (2016), accessed October 24, 2016, http://www. asppb.net/news/news. asp?id=297538.

${ }^{3}$ Ibid.

${ }^{4}$ Nadine J. Kaslow, “Competencies in professional psychology," American Psychologist 59, no. 8 (2004): 774-781.

5 Europsy, “European Diploma in Psychology, 2005,” accessed November 19, 2016, http://www.europsych.org.

${ }^{6}$ Diego E. Rodríguez Cárdenas, ed., Proyecto Tuning América Latina Educación Superior en América Latina: reflexiones y perspectivas en Psicología (Bilbao: Universidad de Deusto, 2013).

7 "Ley Nacional de Educación Superior N²4.521," Ministerio de Educación de la Nación Argentina, accessed October 22, 2016. http://portal.educacion.gov.ar/centro/. 
professional and scientific. Moreover, the Standards set out minimum contents and a minimum theoretical and practical training workload, along with the preparation of a final paper as a requirement for graduation. ${ }^{8},{ }^{9}$ While the Standards are a valuable and relevant contribution to the education of psychologists, they do not lay down the competences needed for such education.

This creates the need to reflect on the competences and core contents of graduate profiles and curricula, so that minimum contents and an adequate and proper training can be provided in the different areas of psychology. ${ }^{10}$

It is worthy of note that Argentina is one of the countries with the highest number of psychologists. In addition, psychology is one of the first five most popular degree choices in Argentina. ${ }^{11}$ This situation should give rise to a permanent assessment of training in psychology, its strengths and weaknesses and improvement plans aimed at enhancing the quality of university education.

\section{The Tuning Latin America Project}

Since the adoption of the Bologna Declaration in 1999, the competencebased approach has been actively promoted by the European Union. These efforts led to the development of the Tuning Project for university training in Europe, which was later adopted by Latin American countries. ${ }^{12}$

The purpose of the Tuning Latin America Project was to exchange information and improve collaboration between higher education institutions,

8 "Resolución 343/09-ME. Educación Superior, Los estándares para la acreditación de las carreras correspondientes a los títulos de Psicólogo y Licenciado en Psicología, 2009, accessed July 11, 2016, http://www.psyche.unc.edu.ar/wp-content/uploads/resolucionministerio-de-educacion-343-20091.pdf.

${ }^{9}$ Resolución 800/11-ME. Educación Superior. Los estándares para la acreditación de las carreras correspondientes a los títulos de Psicólogo y Licenciado en Psicología, 2011, accessed July 11, 2016, http://servicios.infoleg.gob.ar/infolegInternet/anexos/155000-159999/158472/ norma.htm.

${ }^{10}$ Mauricio González, Ingrid González, and Karol Vicencio, "Descripción del rol autopercibido del psicólogo y sus implicancias en los procesos de formación de pregrado," Psicoperspectivas 13, no. 1 (2014): 108-120.

${ }^{11}$ Modesto Alonso, Domenica Klinar, and Paula Gago. "Los/as psicólogos/as en Argentina. Relevamiento Cuantitativo 2011" (paper presented at the IV Congreso Internacional de Investigación y Práctica Profesional en Psicología, XIX Jornada de Investigación y $8^{\circ}$ Encuentro de Investigadores de Psicología del MERCOSUR. Facultad de Psicología de la Universidad de Buenos Aires, Buenos Aires, Argentina, November 28-30, 2012).

${ }^{12}$ Pablo Beneitone et al., Reflexiones y perspectivas de la educación superior en América Latina: informe final, proyecto Tuning América Latina 2004-2007 (Bilbao: Universidad de Deusto, 2007). 
in furtherance of the quality, effectiveness and transparency of qualifications and curricula. ${ }^{13}$

Sixty-two universities belonging to different Latin American countries took part in the Tuning Latin America Project. In addition, another relevant actor participated in the Project: the Tuning National Centres (TNC). ${ }^{14}$

The Tuning Latin America Project comprises four major lines of work: competences (both generic and specific to each thematic area); approaches to teaching, learning and assessment; academic credits; and quality of the curricula. With respect to competences, a questionnaire was administered to graduates, students, employers and academics of different discipline areas in which they were asked about the generic and specific competences of their respective disciplines. The respondents were requested to assess the importance and degree of achievement of each competence and to select the five competences they regarded as the most important. This allowed drawing up a list of generic and specific competences in each thematic area. ${ }^{15}$

The second phase of the Tuning Project included the area of Psychology, and thus the challenge arose to reach agreement on the education of psychologists in the region. ${ }^{16}$

Agreements were sought regarding the competences of those individuals holding undergraduate and graduate degrees in psychology and future professional scenarios. Additionally, teaching, learning and competence assessment strategies were outlined, along with certain considerations concerning students' workload during the course of their studies. ${ }^{17}$

\section{Psychology competences studies in Latin America's students}

In the past few years, studies have been conducted on the specific competences involved in the education of psychologists. However, there has been little research into the specific competences of psychologists set out in the Tuning Latin America Project.

13 Tuning América Latina, Tercera Reunión General (Bilbao: Universidad de Deusto, 2012).

${ }_{14}$ Julia González, Robert Wagenaar, and Pablo Beneitone, "Tuning-América Latina: un proyecto de las universidades," Revista iberoamericana de educación 35,1 (2004): 151-164.

${ }_{15}$ Beneitone et al., Reflexiones y perspectivas de la educación superior en América Latina.

${ }^{16}$ Rodríguez Cárdenas, ed., Proyecto Tuning América Latina Educación Superior en América Latina: reflexiones y perspectivas en Psicología (Bilbao: Universidad de Deusto, 2013).

${ }^{17}$ Ibid. 
In this sense, a research study into the specific competences of psychologists as laid down in the Project was conducted in Costa Rica in order to ascertain their degree of importance and achievement. All of the competences were rated as highly important in the study. The competences that obtained the highest ratings in terms of importance were related to the ethical aspects of professional practice, including ethical commitment and respect for diversity, as well as the capacity to translate theory into specific actions and the ability to understand and intervene in accordance with individuals' context and biopsychosocial reality. ${ }^{18}$

A research study aimed at establishing the competences of psychologists in Colombia's current professional practice found that knowledge of psychology principles, the use of technological tools and problem-solving abilities, along with initiative, human quality and professional ethics, are the most in-demand requirements of professional practice. ${ }^{19}$

In Chile, Álvarez and colleagues ${ }^{20}$ conducted research into the competences that psychologists must have in order to enter the labour market. Students pointed out that such competences relate to adaptability, trustworthiness, innovation, team work and a global view. However, they also stated that they lack the following competences: problem analysis and assessment, technical and professional knowledge, energy, development of alliances, strategic job design, commitment, planning and organization, decision making and tolerance to stress.

Other research studies have sought to identify the competences in which students perceive themselves as more and less competent, and in some cases surveys have been conducted to determine the degree of importance of each competence. By way of example, Manzo $^{21}$ carried out a study in Argentina assessing the self-perception of competences acquired by advanced psychology students. The study found a high self-perception of clinical competences to the detriment of other professional areas.

18 Zaida Salazar-Mora and Jorge E. Prado-Calderón, "Valoración de competencias específicas del profesional en Psicología desde la Universidad de Costa Rica," Revista Costarricense de Psicología 31 (2012): 41-63.

19 Maritza Ruiz, Bruno Jaraba and Lidia Romero, "La formación en psicología y las nuevas exigencias del mundo laboral," Psicología desde el Caribe 21 (2008): 136-157.

${ }^{20}$ Ernesto Álvarez, Jean Gómez, and Paula Ratto, "Competencias requeridas por el mercado laboral chileno y competencias actuales de estudiantes de Psicología con orientación laboral/organizacional, en una universidad privada," Pharos 11, no. 1 (2004): 113-133.

${ }^{21}$ Gustavo Manzo, "Autopercepción de competencias adquiridas en estudiantes de psicología de ciclo profesional (avanzado)," Anuario de proyecto e informes de becarios de investigación de la Facultad de Psicología de la UNMdP 6 (2009): 284-290. 
A study conducted by Herrera and colleagues ${ }^{22}$ in Colombia was aimed at identifying the self-perceived strongest academic and professional competences of students and graduates. According to the study, they perceive themselves as more competent in the organisational area, given their special ability to work in interdisciplinary teams and carry out selection and recruiting tasks. It was found that they perceive themselves as less competent in the field of research and psychological evaluation. Students and graduates also acknowledge that they should improve their ability to communicate in English, to provide assessment and advice in sports activities, and to evaluate and intervene in the area of clinical neuropsychology.

Cabrera and colleague ${ }^{23}$ carried out a survey of the competences rated as most important by a sample of students and professors in Colombia. Such competences include: the ability to listen, management of knowledge, and assessment and understanding. On the other hand, technical abilities, such as the use of psychological tests, were not considered to be as important.

Another study surveyed the self-perception of practical competences of psychology undergraduate students in two state-owned universities in Argentina. Advanced students were asked to complete a questionnaire aimed at identifying the subjective perception of appropriation of the practical competences required for the exercise of the profession. The study contains an analysis of the basic and supplementary competences in the clinical assistance area. ${ }^{24}$

\section{Method}

The purpose of this research is to analyse the degree of importance and perceived achievement of the specific competences set out within the framework of the Tuning Latin America Project, among a sample of advanced psychology students.

${ }_{22}$ Andrea Herrera, María F. Restrepo Álvarez, Ana F. Uribe Rodríguez and Claudia López Lesme, "Competencias académicas y profesionales del psicólogo," Diversitas 5, no. 2 (2009): 241-254.

${ }^{23}$ Piedad Cabrera et al., "La formación en Psicología desde una perspectiva de competencias. Una contribución para el mejoramiento de la formación universitaria en Chile," Calidad en la Educación 33 (2010): 183-223.

${ }^{24}$ Catriel Fierro, "La autopercepción de competencias prácticas en estudiantes avanzados de psicología en el marco de los procesos de acreditación” (paper presented at V Congreso Internacional de Investigación y Práctica Profesional en Psicología XX Jornadas de Investigación Noveno Encuentro de Investigadores en Psicología del MERCOSUR, Facultad de Psicología de la Universidad de Buenos Aire, Buenos Aires, Argentina, November 30, 2013). 


\section{Participants}

The sample included 100 students that in 2015 were taking the last two years of the psychology degree course in a private university in the City of Buenos Aires. The students' ages ranged between 21 and 53 years, the mean age being 32 years. $73 \%$ of the participants were women.

Concerning to the psychology program consulted for this paper, it's started 18 years ago, have a duration of 5 years, with training in different areas of psychology and a general view. The students do practical training in institutions linked to the different areas of professional practice supervised in the last stage of the career.

\section{Instrument}

The Specific Competences Survey for students of the Tuning Latin America Project was used. This instrument consists of a list of 24 specific competences. The respondents were asked to rate the importance of each competence for professional practice and the degree of achievement of such competence. ${ }^{25}$

The survey used a four-point Likert scale ranging between $1=$ not important at all; $2=$ of little importance; $3=$ fairly important; and $4=$ very important. ${ }^{26}$

\section{Procedure}

The questionnaire was administered to students of a private university in the City of Buenos Aires. In-person consultations were conducted. The students were asked to attend a meeting where the objectives and the characteristics of the survey were explained to them, and then the printed survey was given out to them.

\section{Results}

In order to evaluate the degree of importance and achievement given by psychology students to the specific competences set out within the framework

${ }^{25}$ Rodríguez Cárdenas, ed., Proyecto Tuning América Latina Educación Superior en América Latina.

${ }^{26}$ Beneitone et al., Reflexiones y perspectivas de la educación superior en América Latina. 
of the Tuning Latin America Project, frequencies, mean scores, and highest and lowest ratings were calculated for each of the 24 competences.

\section{Degree of importance of specific competences}

Specific competences in psychology obtained high ratings in terms of importance, the mean rating being of 3.51. All competences were rated above 2.93 and the highest mean rating was 3.85 .

Table 1 shows the five competences with the highest mean ratings in terms of importance.

Table 1

Specific competences with the highest mean ratings in terms of importance

\begin{tabular}{|l|c|c|c|c|}
\hline \multicolumn{1}{|c|}{ Competences } & $\begin{array}{c}\text { Lowest } \\
\text { rating }\end{array}$ & $\begin{array}{c}\text { Highest } \\
\text { rating }\end{array}$ & $\begin{array}{c}\text { Mean } \\
\text { rating }\end{array}$ & $\begin{array}{c}\text { Standard } \\
\text { deviation }\end{array}$ \\
\hline $\begin{array}{l}\text { 24. Accept the ethical commitment of } \\
\text { psychological practice }\end{array}$ & 3 & 4 & 3.85 & 0.35 \\
\hline $\begin{array}{l}\text { 11. Establish relationships between the } \\
\text { theory and practice of psychology }\end{array}$ & 1 & 4 & 3.82 & 0.52 \\
\hline $\begin{array}{l}\text { 8. Understand human beings' transitional } \\
\text { stages throughout the life cycle }\end{array}$ & 3 & 4 & 3.8 & 0.40 \\
\hline $\begin{array}{l}\text { 22. Respect individual and sociocultural } \\
\text { diversity }\end{array}$ & 2 & 4 & 3.78 & 0.46 \\
\hline $\begin{array}{l}\text { 13. Understand and intervene in human } \\
\text { beings' psychological problems in } \\
\text { accordance with their social, cultural and } \\
\text { economic context }\end{array}$ & 2 & 4 & 3.71 & 0.47 \\
\hline
\end{tabular}

In turn, 22 competences obtained mean ratings above 3 . This shows that they were considered as fairly and very important by the students surveyed. Only two of such competences obtained mean ratings below 3 , although in both cases ratings were close to that value. Such competences were related to the integration of technological tools into professional practice (mean of 2.93) and the ability to design psychometric tools in a valid and reliable manner (mean of 2.99).

With respect to lowest and highest ratings, it was found that two competences obtained minimum ratings of 3 (none of the respondents rated such competences below that value). These competences were related to the 
acceptance of the ethical commitment of psychological practice and an understanding of human beings' transitional stages throughout the life cycle. These were two of the competences with the highest mean ratings.

Table 2 shows the five competences with the lowest mean ratings in terms of importance.

Table 2

Specific competences with the lowest mean ratings in terms of importance

\begin{tabular}{|l|c|c|c|c|}
\hline \multicolumn{1}{|c|}{ Competences } & $\begin{array}{c}\text { Lowest } \\
\text { rating }\end{array}$ & $\begin{array}{c}\text { Highest } \\
\text { rating }\end{array}$ & $\begin{array}{c}\text { Mean } \\
\text { rating }\end{array}$ & $\begin{array}{c}\text { Standard } \\
\text { deviation }\end{array}$ \\
\hline $\begin{array}{l}\text { 19. Integrate technological tools into } \\
\text { professional practice }\end{array}$ & 1 & 4 & 2.93 & 0.78 \\
\hline $\begin{array}{l}\text { 21. Design psychometric tools in a valid } \\
\text { and reliable manner }\end{array}$ & 1 & 4 & 2.99 & 0.93 \\
\hline $\begin{array}{l}\text { 3. Carry out scientific research in the field } \\
\text { of psychology }\end{array}$ & 1 & 4 & 3.23 & 0.75 \\
\hline $\begin{array}{l}\text { 2. Know and understand the } \\
\text { epistemological foundations of science }\end{array}$ & 1 & 4 & 3.27 & 0.63 \\
\hline $\begin{array}{l}\text { 14. Mediate and/or negotiate in different } \\
\text { aspects of psychological practice }\end{array}$ & 1 & 4 & 3.31 & 0.76 \\
\hline
\end{tabular}

In addition, the importance of the competences was analysed in connection with the five domains into which the 24 competences are classified. It is worth recalling that the Tuning Latin America Project in the area of Psychology not only included a list of specific competences, but it also developed a meta-profile in which the different competences are classified into several domains.

Regarding mean ratings for each domain, the highest mean was obtained by the Ethical Domain (3.77), followed by the Disciplinary Domain (3.67), while the Interdisciplinary Domain ranked third (3.49) and the Professional Domain was placed fourth (3.48). The Epistemological Domain ranked last (3.36). It may be noted that there is very little variation in the mean ratings of each domain.

\section{Self-perceived degree of achievement of specific competences}

Regarding the self-perceived degree of achievement, the mean rating was 2.96 - with values ranging between 2.39 and 3.43. The following table 
shows the five competences with the highest mean ratings of achievement according to students (Table 3 ).

Table 3

Specific competences with the highest mean ratings for self-perceived achievement

\begin{tabular}{|l|c|c|c|c|}
\hline \multicolumn{1}{|c|}{ Competences } & $\begin{array}{c}\text { Lowest } \\
\text { rating }\end{array}$ & $\begin{array}{c}\text { Highest } \\
\text { rating }\end{array}$ & $\begin{array}{c}\text { Mean } \\
\text { rating }\end{array}$ & $\begin{array}{c}\text { Standard } \\
\text { deviation }\end{array}$ \\
\hline $\begin{array}{l}\text { 24. Accept the ethical commitment of } \\
\text { psychological practice }\end{array}$ & 1 & 4 & 3.43 & 0.79 \\
\hline $\begin{array}{l}\text { 3. Carry out scientific research in the field } \\
\text { of psychology }\end{array}$ & 1 & 4 & 3.35 & 0.78 \\
\hline $\begin{array}{l}\text { 7. Understand and explain psychological } \\
\text { processes from a biopsychosocial } \\
\text { perspective }\end{array}$ & 2 & 4 & 3.35 & 0.62 \\
\hline $\begin{array}{l}\text { 8. Understand human beings' transitional } \\
\text { stages throughout the life cycle }\end{array}$ & 2 & 4 & 3.31 & 0.64 \\
\hline $\begin{array}{l}\text { 11. Establish relationships between the } \\
\text { theory and practice of psychology. }\end{array}$ & 2 & 4 & 3.29 & 0.76 \\
\hline
\end{tabular}

For all competences, the highest rating was 4 , and the lowest in these five competences was 2 (of little importance).

In relation to the five competences with the lowest mean ratings for achievement, the mean ratings varied between 2.68 and 2.39.

\section{Table 4}

Specific competences with the lowest mean ratings for self-perceived achievement

\begin{tabular}{|l|c|c|c|c|}
\hline \multicolumn{1}{|c|}{ Competences } & $\begin{array}{c}\text { Lowest } \\
\text { rating }\end{array}$ & $\begin{array}{c}\text { Highest } \\
\text { rating }\end{array}$ & $\begin{array}{c}\text { Mean } \\
\text { rating }\end{array}$ & $\begin{array}{c}\text { Standard } \\
\text { deviation }\end{array}$ \\
\hline $\begin{array}{l}\text { 19. Integrate technological tools into } \\
\text { professional practice }\end{array}$ & 1 & 4 & 2.39 & 0.96 \\
\hline $\begin{array}{l}\text { 16. Design and develop programmes that } \\
\text { promote the psychological well-being of } \\
\text { individuals, groups and communities }\end{array}$ & 1 & 4 & 2.41 & 0.85 \\
\hline $\begin{array}{l}\text { 21. Design psychometric tools in a valid } \\
\text { and reliable manner }\end{array}$ & 1 & 4 & 2.45 & 0.93 \\
\hline
\end{tabular}




\begin{tabular}{|l|c|c|c|c|}
\hline \multicolumn{1}{|c|}{ Competences } & $\begin{array}{c}\text { Lowest } \\
\text { rating }\end{array}$ & $\begin{array}{c}\text { Highest } \\
\text { rating }\end{array}$ & $\begin{array}{c}\text { Mean } \\
\text { rating }\end{array}$ & $\begin{array}{c}\text { Standard } \\
\text { deviation }\end{array}$ \\
\hline $\begin{array}{l}\text { 14. Mediate and/or negotiate in different } \\
\text { aspects of psychological practice }\end{array}$ & 1 & 4 & 2.59 & 0.92 \\
\hline $\begin{array}{l}\text { 5. Integrate and make use of knowledge } \\
\text { of other disciplines }\end{array}$ & 1 & 4 & 2.68 & 0.80 \\
\hline
\end{tabular}

\section{Conclusion}

It is worth noting that the students regarded all the competences as highly important. This shows that, for the students in the sample, all the items listed entail different areas of knowledge and skills that are valued as highly necessary for the practice of Psychology. This is in line with the findings of the Tuning Latin America Project, in which all the competences were rated as important by students. ${ }^{27}$

It should be stressed that the competence considered by the students to be the most important was the one related to the ethical aspect of professional practice. Accepting the ethical commitment of psychological practice was the competence with the highest rating in terms of importance.

Similar findings were reported by the Tuning Latin America Project, as ethics-related general and specific competences obtained the highest mean ratings in terms of importance among all the groups surveyed..$^{28}$

Along these lines, the need to include ethics in university curricula has been acknowledged and thus training in ethics has been gradually incorporated into the teaching and learning processes of the different professional disciplines. $^{29}$

In this sense, university education is not only concerned with generating and transmitting knowledge, but it is also committed to providing students with integral training that includes specialised field knowledge, technical skills and a framework for ethical professional practice that should also be considered as a moral activity. ${ }^{30}$

27 Tuning América Latina, Tercera Reunión General.

28 Tuning América Latina, Tercera Reunión General.

${ }^{29}$ UNESCO, "Hacia las sociedades del conocimiento. Informe mundial de la UNESCO," 2005, accessed October, 12, 2016, http://unesdoc.unesco.org/images/0014/001419/141908s. pdf.

30 Antonio Bolívar, "El lugar de la ética profesional en la formación universitaria," Revista mexicana de investigación educativa 10, no. 24 (2005): 93-123. 
It is widely recognised that education that prepares a prospective psychologist for a valuable intervention in the community needs to approach the profession's ethical-deontological dimension. ${ }^{31}$

Research studies carried out in Argentina, ${ }^{32}$ Costa Rica, ${ }^{33}$ Mexico $^{34}$ and Colombia ${ }^{35}$ show that the most important competences are those related to the ethical aspects of professional practice, including ethical commitment and respect for diversity.

Therefore, ethical competences in professional education are considered to be of great relevance both for students and graduates. They also prove to be relevant in university curricula and professional regulations, in which ethical aspects play a central role. Ethics is a necessary component of current professional education, as it is considered by the different actors of the educational process to be the foundation for personal and professional development. $.^{36},{ }^{37},{ }^{38},{ }^{39},{ }^{40}$

On the other hand, it is relevant to make reference to some of the competences that obtained the lowest mean ratings in terms of importance. One of such competences is the ability to integrate technological tools into professional practice. The low importance given to this competence seems

31 Andrea Ferrero and Eugenia Andrade, "Propuestas vigentes para la formación éticodeontológica en Carreras de Psicología en el contexto del Mercosur. El caso argentino," Fundamentos en Humanidades 15 (2007): 163-178.

${ }^{32}$ María J. Sanchez Vazquez, "La ética y deontología profesional en el proceso de formación académica de los alumnos de la Facultad de Psicología," Revista de PsicologíaSegunda Época 12 (2011): 109-125.

${ }^{33}$ Zaida Salazar-Mora and Jorge E. Prado-Calderón, "Valoración de competencias específicas del profesional en Psicología desde la Universidad de Costa Rica," Revista Costarricense de Psicología 31 (2012): 41-63.

${ }^{34}$ Guadalupe Ross Argüelles et al., "Evaluación de competencias y su relación con el desempeño de los estudiantes en la práctica profesional", Revista El Buzón de Pacioli 74 (2011): 1-15.

${ }^{35}$ Maritza Ruiz, Bruno Jaraba, and Lidia Romero, "La formación en psicología y las nuevas exigencias del mundo laboral," Psicología desde el Caribe 21(2008): 136-157.

${ }^{36}$ Ferrero, Andrea, and Eugenia Andrade, "Propuestas vigentes para la formación éticodeontológica en Carreras de Psicología en el contexto del Mercosur. El caso argentino," Fundamentos en Humanidades 15 (2007): 163-178.

37 Ross Argüelles et al., Evaluación de competencias y su relación con el desempeño de los estudiantes en la práctica profesional, 1-15.

${ }^{38}$ Ruiz, Jaraba, and Romero, "La formación en psicología y las nuevas exigencias del mundo laboral," 136-157.

${ }^{39}$ Salazar-Mora and Prado-Calderón, "Valoración de competencias específicas del profesional en Psicología desde la Universidad de Costa Rica," 41-63.

${ }^{40}$ Sanchez Vazquez, "La ética y deontología profesional en el proceso de formación académica de los alumnos de la Facultad de Psicología," 109-125. 
remarkable if we consider the prominence of technology in today's society. Such low rating, however, does not seem to be an isolated finding in this study. Other studies have reported similar findings regarding the low importance placed on integrating technological tools into professional practice. $^{41} 4243$

Technological tools are gradually being implemented in Psychology, through the use of the Internet and new tools that assist in evaluation and intervention, such as simulation, virtual reality and augmented reality ${ }^{44}$ The possibilities that new technologies offer for psychology show a promising future, but their implementation poses a great challenge. ${ }^{45}$

Another competence rated with a low level of importance was the ability to design psychometric tools in a valid and reliable manner. This is a competence that is generally regarded by students and graduates as unimportant $.^{46},{ }^{47}$

Some comments regarding this point are in order. Measurement in psychology is extremely relevant as it makes it possible to gather data about abilities, behavioural traits, personality types and other features that allow professionals to quantify human characteristics. ${ }^{48}$ However, administering psychometric tools is not the same as designing them. While psychologists in different professional areas usually administer evaluation techniques in the diagnosis process, the design of evaluation tools is not a common practice in psychology - these are generally developed in academic contexts within research processes.

In addition to this, it is worth recalling that in Argentina the psychologist's profile has had a strong clinical character, while psychometrics, statistics and methodology have been less developed.

${ }^{41}$ Salazar-Mora and Prado-Calderón, "Valoración de competencias específicas del profesional en Psicología desde la Universidad de Costa Rica," 41-63.

${ }^{42}$ Sanchez Vazquez, "La ética y deontología profesional en el proceso de formación académica de los alumnos de la Facultad de Psicología," 109-125.

${ }^{43}$ Tuning América Latina, Tercera Reunión General.

${ }^{44}$ Cristina Botella et al., "La utilización de las nuevas tecnologías de la información y la comunicación en psicología clínica," UOC Papers: revista sobre la societat del coneixement 4 (2007): 32-40.

45 Jordi Miró, "Psicoterapia y nuevas tecnologías," Cuadernos de Medicina Psicosomática y Psiquiatría de Enlace 81 (2007): 15-20.

${ }_{46}$ Piedad Cabrera et al., "La formación en Psicología desde una perspectiva de competencias. Una contribución para el mejoramiento de la formación universitaria en Chile," Calidad en la Educación 33 (2010): 183-223.

47 Tuning América Latina, Tercera Reunión General.

48 Diana Malo Salavarrieta, "La medición en psicología como herramienta y como reflexión ética en el ejercicio del psicólogo,” Revista Psicogente 11 (2008): 46-51. 
This explains why students do not regard this as a central competence in the profession and a common practice, but rather as a specific field of knowledge and ability related to a particular area.

Regarding the self-perceived degree of achievement of specific competences, it is worth noting that the students surveyed considered that most of the competences are thoroughly developed during their professional training in Psychology.

It is also worth stressing that the competence with the highest selfperceived degree of achievement was the ability to accept the ethical commitment of psychological practice.

It is encouraging to find that students perceive high levels of achievement in ethical competences since these competences are one of the pillars for a responsible professional practice that is committed to society.

In addition, the students regarded the ability to carry out scientific research as one of the competences with the highest degree of achievement. This result is not consistent with the findings reported in other studies, as such ability is generally regarded as an area with a low competence requiring improvement. ${ }^{49}, 50$

On the other hand, it is also relevant to focus on those competences with perceived low levels of achievement. The data gathered in this respect is useful to reflect upon the role of these competences in psychologists' education and open a debate about the need to provide more thorough training in these competences.

One of these competences is the ability to design and develop programmes that promote psychological well-being. This is a competence that is regarded as highly important but with respect to which students and graduates do not feel competent enough. This draws our attention to one of the main shifts in psychology in the past few years: the growing interest in well-being and individual strengths, in a move away from a focus on pathological aspects. The findings obtained from the students' survey point in this direction.

Along these lines, the interest of psychology throughout time has been focused on the negative aspects of the individual, which resulted in a disciplinary framework biased towards pathological aspects. As a

49 Andrea Herrera et al., "Competencias académicas y profesionales del psicólogo," Diversitas 5.2 (2009): 241-254.

${ }^{50}$ Mauricio González, Ingrid González, and Karol Vicencio, "Descripción del rol autopercibido del psicólogo y sus implicancias en los procesos de formación de pregrado," Psicoperspectivas 13.1 (2014): 108-120. 
consequence of this approach, there has been little progress in the study of strategies to optimise the individual's resources. ${ }^{51}$

However, this approach has changed over the past few years. A trend has emerged in psychology that addresses positive variables and preventive measures instead of focusing on the traditional negative and pathological aspects. ${ }^{52}$

This shift may be attributed to the introduction of Positive Psychology by Seligman in 1998. The scientific community thus became interested in concepts such as happiness, well-being, optimism and wisdom. ${ }^{53}$

It was at that time that the concept of well-being became prominent in the scientific community, which now regards Psychology not only as the study of pathologies and damage, but also of strengths and virtues. Psychological treatment should not only focus on fixing what is broken but also nurture what is best within ourselves. ${ }^{54}$

The statements above are closely related to the ability to design programmes that promote well-being. It would be particularly helpful to increase efforts so that students and graduates may enhance their degree of achievement in this area.

To conclude, it is important to reflect upon the essential competences that should be included in academic curricula so as to guarantee a minimum, sufficient and relevant training in all professional areas where psychologists may intervene.

This creates the need for a constant assessment of training, its strengths and weaknesses and improvement plans aimed at enhancing the quality of university education.

At present, the only project that evaluates the competences required for the practice of psychology in Latin American is the Tuning Latin America Project. In some countries of the region, however, there have been proposals to establish a list of competences at the national level - such has been the case in Chile and Colombia.

In Argentina, this area has not been adequately studied. For this reason, it is worth emphasising that the findings in this research provide evidence that the competences set out within the framework of the Tuning Latin

${ }^{51}$ Carmelo Vázquez, "La psicología positiva en perspectiva," Papeles del psicólogo 27, no. 1 (2006): 1-2.

52 María Laura Lupano Perugini and Alejandro Castro Solano, "Psicología positiva: análisis desde su surgimiento." Ciencias psicológicas 4, no. 1 (2010): 43-56.

53 Martin Seligman, “The president's address," American Psychologist 54 (1999): 559-532.

${ }^{54}$ Martin Seligman,’Fundamental assumptions,” Psychologist 16, no. 3 (2003): 126-127. 
America Project are regarded as highly relevant by the university students that participated in the survey.

\section{Bibliography}

Alonso, Modesto, Domenica Klinar, and Paula Gago. "Los/as psicólogos/as en Argentina. Relevamiento Cuantitativo 2011.” Paper presented at IV Congreso Internacional de Investigación y Práctica Profesional en Psicología, XIX Jornada de Investigación y $8^{\circ}$ Encuentro de Investigadores de Psicología del MERCOSUR. Facultad de Psicología de la Universidad de Buenos Aires, Buenos Aires, Argentina, November 28-30, 2012.

Álvarez, Ernesto, Jean Gómez, and Paula Ratto. "Competencias requeridas por el mercado laboral chileno y competencias actuales de estudiantes de Psicología con orientación laboral/organizacional, en una universidad privada." Pharos 11, no.1 (2004): 113-133.

Beneitone, Pablo, César Esquetini, Julia González, Maida M. Maleta, Gabriela Siufi, and Robert Wagenaar. Reflexiones y perspectivas de la educación superior en América Latina: informe final, proyecto Tuning América Latina 2004-2007. Bilbao: Universidad de Deusto, 2007.

Bolívar, Antonio. "El lugar de la ética profesional en la formación universitaria." Revista mexicana de investigación educativa 10, no. 24 (2005): 93-123.

Botella, Cristina, Rosa Baños Rivera, Azucena García Palacios, Soledad Quero, Verónica Guillén and José Marco Heliodoro. "La utilización de las nuevas tecnologías de la información y la comunicación en psicología clínica." UOC Papers: revista sobre la societat del coneixement 4 (2007): 32-40.

Cabrera, Piedad, Antonia Larraín, Renato Moretti, Mauricio Arteaga, and Alejandra Energici. "La formación en Psicología desde una perspectiva de competencias. Una contribución para el mejoramiento de la formación universitaria en Chile." Calidad en la Educación 33 (2010): 183-223.

Europsy. "European Diploma in Psychology." Accessed November, 19, 2016, http:// www.europsych.org.

Ferrero, Andrea, and Eugenia Andrade. "Propuestas vigentes para la formación ético-deontológica en Carreras de Psicología en el contexto del Mercosur. El caso argentino." Fundamentos en Humanidades 15 (2007): 163-178.

Fierro, Catriel. "La autopercepción de competencias prácticas en estudiantes avanzados de psicología en el marco de los procesos de acreditación.” Paper presented at V Congreso Internacional de Investigación y Práctica Profesional en Psicología XX Jornadas de Investigación Noveno Encuentro de Investigadores en Psicología del MERCOSUR. Facultad de Psicología de la Universidad de Buenos Aires, Buenos Aires, Argentina, November 30, 2013.

Fouad, Nadya, Catherine L. Grus, Robert L. Hatcher, Nadine J. Kaslow, Philinda Hutchings, Michael B. Madson, Frank L. Collins, and Raymond Crossman. 
"Competency benchmarks: A model for understanding and measuring competence in professional psychology across training levels." Training and Education in Professional Psychology 3, no. 4 (2009): 5-26.

González, Mauricio, Ingrid González, and Karol Vicencio. "Descripción del rol autopercibido del psicólogo y sus implicancias en los procesos de formación de pregrado." Psicoperspectivas 13, no. 1 (2014): 108-120.

González, Julia, Robert Wagenaar, and Pablo Beneitone. "Tuning-América Latina: un proyecto de las universidades." Revista iberoamericana de educación 35, no.1 (2004): 151-164.

Herrera, Andrea, María F. Restrepo Álvarez, Ana F. Uribe Rodríguez and Claudia López Lesme. "Competencias académicas y profesionales del psicólogo.” Diversitas 5, no. 2 (2009): 241-254.

International Project on Competence in Psychology. "International Declaration on Core Competences in Professional Psychology." Accessed October 24, 2016. http://www .asppb.net/news/news.asp?id=297538.

Kaslow, Nadine J. "Competencies in professional psychology." American Psychologist 59, no. 8 (2004): 774-781.

Ley Nacional de Educación Superior $N^{\circ} 24.521$. Ministerio de Educación de la Nación Argentina. Accessed October, 22, 2016. http://portal.educacion.gov.ar/ centro/.

Lupano Perugini, María Laura, and Alejandro Castro Solano. "Psicología positiva: análisis desde su surgimiento.” Ciencias psicológicas 4, no. 1 (2010): 43-56.

Malo Salavarrieta, Diana. "La medición en psicología como herramienta y como reflexión ética en el ejercicio del psicólogo.” Revista Psicogente 11 (2008): 46-51.

Manzo, Gustavo. "Autopercepción de competencias adquiridas en estudiantes de psicología de ciclo profesional (avanzado)." Anuario de proyecto e informes de becarios de investigación de la Facultad de Psicología de la UNMdP 6 (2009): 284-290.

Miró, Jordi. "Psicoterapia y nuevas tecnologías." Cuadernos de Medicina Psicosomática y Psiquiatría de Enlace 81 (2007): 15-20.

Resolución 343/09-ME. Educación Superior. Los estándares para la acreditación de las carreras correspondientes a los títulos de Psicólogo y Licenciado en Psicología, 2009. Accessed July, 11, 2016. http://www.psyche.unc.edu.ar/wpcontent/uploads/resolucion-ministerio-de-educacion-343-20091.pdf.

Resolución 800/11-ME. Educación Superior. Los estándares para la acreditación de las carreras correspondientes a los títulos de Psicólogo y Licenciado en Psicología, 2011. Accessed July, 11, 2016. http://servicios.infoleg.gob.ar/ infolegInternet/anexos/15500059999/158472/norma.html.

Rodríguez Cárdenas, Diego E. ed. Proyecto Tuning América Latina Educación Superior en América Latina: reflexiones y perspectivas en Psicología. Bilbao: Universidad de Deusto, 2013.

Ross Argüelles, Guadalupe, Ricardo Pérez Ibarra, Eneida Ochoa Ávila, Santa Magdalena Mercado Ibarra, Dora Ramos, and Mirsha Sotelo Castillo. 
"Evaluación de competencias y su relación con el desempeño de los estudiantes en la práctica profesional." Revista El Buzón de Pacioli 74 (2011): 1-15.

Ruiz, Maritza, Bruno Jaraba, and Lidia Romero. "La formación en psicología y las nuevas exigencias del mundo laboral." Psicología desde el Caribe 21 (2008): 136-157.

Salazar-Mora, Zaida, and Jorge E. Prado-Calderón. "Valoración de competencias específicas del profesional en Psicología desde la Universidad de Costa Rica." Revista Costarricense de Psicología 31 (2012): 41-63.

Sanchez Vazquez, María J. "La ética y deontología profesional en el proceso de formación académica de los alumnos de la Facultad de Psicología." Revista de Psicología-Segunda Época 12 (2011): 109-125.

Seligman, Martin. "The president's address." American Psychologist 54 (1999): 559-532.

Seligman, Martin. "Positive psychology: Fundamental assumptions." Psychologist 16, no. 3 (2003): 126-127.

Tuning América Latina. Tercera Reunión General. Bilbao: Universidad de Deusto, 2012.

UNESCO. Hacia las sociedades del conocimiento. Informe mundial de la UNESCO, 2005. Accessed October, 12, 2016. http://unesdoc.unesco.org/images/ 0014/001419/141908s.pdf.

Vázquez, Carmelo. "La psicología positiva en perspectiva." Papeles del psicólogo 27, no. 1 (2006): 1-2.

\section{About the authors}

DENISE BENATUIL (dbenatuil@iname.com), PhD in Psychology, is Director of Undergraduate Psychology Studies at Palermo University (Argentina) where she teaches in undergraduate and postgraduate programmes on the following subjects: Internships in Psychology I, II and Practicum. She also teaches at the postgraduate level at the Buenos Aires University (Argentina). She is currently involved in three research projects. The first one is Professional competences and Psychologist profiles which is carried out at the Centre for Higher Education Research at Palermo University and in the context of which many publications have been produced in the last years in reference to the competences for psychology training, the evaluation of competencies according to Tuning Latin America Project in advanced undergraduate students and Psychology graduates, acquisition modalities, internship and practicum as relevant components for the acquisition of competences. The second project is Competences of the Psychologist in different fields of application, carried out at the Centre for Psychology Research at Palermo University. It focuses on the assessment of professional practices as a device for the acquisition of skills in Psychology students. It also explores the skills needed for the expert development of the clinical psychologist. The third project is entitled Exploring the Global Well- 
being of Children and Youth. Methodological Challenges and practices of Undertaking Qualitative Research on Well-being from Multinational Perspectives and is hosted by the Centre for Research in Social Science (CICS) at Palermo University.

MARÍA JULIANA LAURITO (mlauri@palermo.edu) holds a Master's in Higher Education (MEs) from Palermo University (Argentina) where she Secretary of Psychology Degree Programme and teaches at the undergraduate level the following subjects: Internships in Psychology I and II. She currently participates in the following research projects: Professional competences and Psychologist profiles; Competences of the Psychologist in different fields of application, and Exploring the Global Well-being of Children and Youth. Methodological Challenges and practices of Undertaking Qualitative Research on Well-being from Multinational Perspectives. Within the framework of the first project, many publications have been produced during the last years in reference to the competences for psychology training, the evaluation of competencies according to Tuning Latin America Project in advanced undergraduate students and Psychology graduates, acquisition modalities, internship and practicum as relevant components for the acquisition of competences. The lead department for the first project is the Centre for Higher Education Research at Palermo University. The second project is hosted by the Centre for Psychology Research at Palermo University. It focuses on the assessment of professional practices as a device for the acquisition of skills in Psychology students. It also explores the skills needed for the expert development of the clinical psychologist. The lead department for the third project is the Centre for Research in Social Science (CICS) at Palermo University. 


\section{Specific competences in the Tuning Latin America Project: their degree of importance and achievement among a sample of psychology students}

Denise Benatuil and María Juliana Laurito

\section{Copyright}

Copyright for this article is retained by the Publisher. It is an Open Access material that is free for download, distribution, and or reuse in any medium only for non-commercial purposes; provided any applicable legislation is respected, the original work is properly cited, and any changes to the original are clearly indicated. 